\title{
ALTERNATIVE MODEL FOR CORPORATE SOCIAL AND ENVIRONMENTAL RESPONSIBILITY: ACTIVE, PARTICIPATIVE, AND JUST
}

\author{
Arif Firmansyah*, Lina Jamilah", and Sri Ratna Suminar ${ }^{* * *}$
}

Civil Law Department, Faculty of Law Universitas Islam Bandung, Bandung

Jalan Rangga Gading No. 8 Bandung, Jawa Barat 40116

\section{Abstract}

In this study, will be assessed the implementation of corporate social responsibility by coal corporate to look for an alternative model of corporate social responsibility and environtment protection in the context of protecting and managing of natural resources with environmentally concept. Juridical with conceptual approach, the source analysis data technique derived from literature studies and documents.

Keyword: corporate, social, responsibility, environment, protection.

\section{Intisari}

Dalam penelitian ini akan dikaji pelaksanaan tanggung jawab sosial perusahaan dan lingkungan oleh perusahaan batubara untuk kemudian mencari model alternatif tanggung jawab sosial perusahaan dan lingkungan dalam konteks perlindungan dan pengelolaan sumberdaya alam yang berwawasan lingkungan. Metode penelitian yang digunakan dalam penelitian ini adalah yuridis normatif dengan pendekatan undangundang dan pendekatan konseptual, sumber data yang digukana diperoleh dari studi kepustakaan, teknik analisa data diperoleh dari studi literatur dan dokumen.

Kata Kunci: perusahaan, sosial, tanggung jawab, lingkungan, perlindungan.

\section{Pokok Muatan}

A. Introduction 187

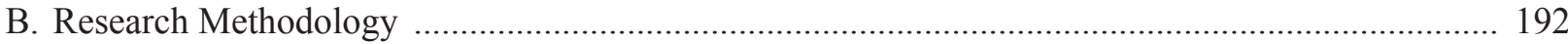

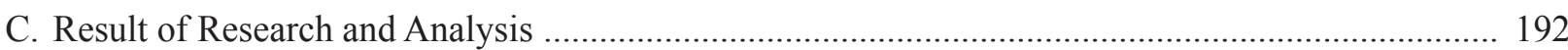

1. Alternative Model for Corporate Social and Environmental Responsibility: Active, Participative, and Just

D. Conclusion

*** Correspondence address: sriratnasuminar@yahoo.com 


\section{A. Introduction}

The environment of Indonesia given by God Almighty to its peoples is His grace and mercy, which function is to be preserved and its capability developed to remain as resources and support to the people of Indonesia. Pancasila as the foundation and philosophy of the nation is a full and rounded unity that gives confidence to the people of Indonesia, that the highest quality of life will be achieved if it is based on harmony, harmony, and balance, both in man's relationship with God Almighty and between men, man and nature, and man as a person in order to achieve progress both material and spiritual.

In society guided by Pancasila, man seeks balance between life as a person and a member of the society, both material and spiritual. A man guided by Pancasila and God Almighty, other than homo economics, is also homo-metafisicus and homo mysticus. The perspective of economy based on Pancasila views not only from economic instinct but also a man as a whole. A man as a whole thinks, behaves and acts not only due to economic stimulus but also to other social and moral factors. Social factors in his relationship with other man and society and moral factor in his relationship with God as his creator. ${ }^{1}$

Pancasila economy is an in institutional economis Pancasila economics is an institutional economics that upholds the institutional values of Pancasila as the state ideology, which 5 (five) principles may, as a whole or individually, be a reference to every Indonesian. As Pancasila contains 5 (five) principles, then all the substance of Pancasila, namely ethics; humanity; nationalism; citizenship/democracy; and social justice, should be considered in the assembled model of economy. The first and second principles are the foundation, while the third and the fouth principles are the methods, and the fifth principle of Pancasila is the purpose of Pancasila economics. ${ }^{2}$

The 1945 Constitution of the Republic of Indonesia states that every person has the right to prosper physically and spiritually, ownership of a home and access to good and healthy living environment. Such is the constitutional rights for every citizen of Indonesia. Therefore, the State or the government and all stakeholders are obliged to conduct protection to the environment and management in the implementation of sustainable development, so that the Indonesian environment can be a source of life and support for the people of Indonesia as well as other living creatures.

In relation to natural resources, Article 33 paragraph (3) of the 1945 Constitution of the Republic of Indonesia ${ }^{3}$ emphasizes that "the earth, water and natural resources shall be under the powers of the State and shall be used to the greatest benefit of the people". The etimology of "be under the powers of the State" (passive) means the control or be under the control of the State (active). The meaning of "control" is "to control over (something), "to have authority (over something)", while the meaning of "to be controlled" refers to the process, method, act, authority or attempt. ${ }^{4}$

According to a judgment by the Constitutional Cort, the right of the State is not in the meaning of ownership, but in the meaning that the State formulates policies (beleid), makes arrangements (regelendaad), maintains (besturdaad), manages (beheerdaad), and controls (toezichthoundendaad). The framework of State control over mining implies that the State holds the power to dominate and exploit all the resources of minerals contained in the Indonesian mining jurisdiction. Acquisition

\footnotetext{
R. Gunawan Sudarmanto, "Konsep Dasar Ekonomi Pancasila”, http://blog.unila.ac.id/radengunawans/files/2010/Makalah..., accessed 1 October 2015.

Ibid.

In its development, after the fourth amendment of the 1945 Consitution on August 10, 2002, the Article received addition in the form of 2 (two) new paragraphs: Article 33 paragraph (4) The organisation of the national economy shall be conducted on the basis of economic democracy upholding the principles of togetherness, efficiency with justice, continuity, environmental perspective, self-sufficiency, and keeping a balance in the progress and unity of the national economy. Paragraph (5) Further provisions relating to the implementation of this article shall be regulated by law.

Ministry of Education and Culture \& National Library, 1995, Kamus Besar Bahasa Indonesia, Jakarta, p. 533.
} 
and utilization of natural resources as defined in (Article 33 paragraph (3) of the 1945 Constitution) refers to the control of the State, which does not limit the management or operation to the State or government bureaucracy, but it may be handed over to private enterprises, provided the activity remains under the control state or government. ${ }^{5}$ Transform to the private sector may occur in the form of State institutions or State-owned corporations. ${ }^{6}$ State mining companies that seek strategic minerals and is given full authority to conduct its business, including the relationship with the third party, provided that all the progress and results of production remain under the control and supervision of the State. ${ }^{7}$

In relation to the functions of the State, Friedman asserts the four functions of the State in the economic field, namely: First, the function of the state as provider of the welfare of society; Second, the function of the State as regulator; Third, the function of the State as entrepeneur or maneger of the particular sector through Stateowned companies; and Fourth, the function of the State as an umpire (watchdogs, referee) to formulate a fair standard of the performance of economic sectors, including State-owned companies. ${ }^{8}$

In carrying out the functions of the state in the economic field, Indonesia adopts economy based on democracy. The system requires economic empowerment of the people as a whole given the widest possible opportunity to participate and master all brances of production. The creation of the economic climate is not just left to the market forces, but requires State intervention, both directly by the State-owned companies and indirectly in the form of regulation or without. ${ }^{9}$
The existence of the company is instrumental in the welfare of the surrounding community, through the absorption of workers coming from the surrounding community. In conducting its business, a company does not only have economic obligation but have an ethical obligation. In the fulfillment of business ethics, the main goal is not profit, but community empowerment must be the main objective for the company. Such is one of the manifestations of good corporate by the company towards stakeholders. ${ }^{10}$

The company's efforts in empowering the community and the environment in general is referred to as Corporate Social Responsibility (CSR) or corporate citizenship and is intended to encourage businesses to be more ethical in carrying out its activities in order to have no effect or a negative impact on the community and environment, so that in the end the business environment will be able to survive in a sustainable manner to obtain economic benefits that is the purpose of establishing business. ${ }^{11}$

In order to realize the sustainable activities of the company, the company applies the principles of corporate social responsibility which is hereinafter referred to as CSR and the environment, which is the contribution of the business world for the realization of sustainable development. Development of a country is not only the responsibility of the government alone; every human being instrumental to achieve social welfare and improving the quality of life of the people. The business world plays to encourage healthy economic growth by taking into account environmental factors. ${ }^{12}$

\footnotetext{
Mohammad Hatta, 1967, Ekonomi Terpimpin, Djambatan, Jakarta, p. 46.

For example Oil and Natural Gas company by Pertamina and PT Gas Negara, Electricity by PT PLN and other kinds of public utilities.

Abrar Saleng, 2004, Hukum Pertambangan, Cet. 2, UII Press, Yogyakarta, p. 31.

Ibid., p. 16.

Ibid., p. 3.

Rosita Chandra Kirana, 2009, Studi Perbandingan Pengaturan tentang Corporate Sosial Responsibility di Beberapa Negara dalam Perwujudan Prinsip Good Corporate Governance, Thesis, Master Program Universitas Sebelas Maret, Surakarta, p. 11.

1 Buku Panduan Rakor dan Pameran Program Tanggung Jawab Sosial (CSR/PKBL) Perusahaan sebagai Alternatif Pembiayaan Pembangunan di Jawa Timur, p. 2.

12 Elkington developed the concept of Triple bottom line in the term economic prosperity, environmental quality, and sosial justice. Elkington provides a perspective that $\mathrm{f}$ a company intends to continue its survival, then the company must give due attention to " $3 \mathrm{P}$ '. Other than desire for profit, company must regard and be involved in fulfilling the welfare of the people and actively contribute in preserving the environment. See also Gunawan Widjaya, et al., 2009, Risiko Hukum \& Bisnis Perusahaan Tanpa CSR, Forum Sahabat, Jakarta, p. 33.
} 
In principle, social and environmental responsibility is an effort that starts from the awareness of companies and is voluntary in nature. The genesis of corporate social responsibility and the environment stems from philanthropy activities (humanitarian contribution) companies that often are spontaneous and have not been managed well. Along with the development of society and the business world as well as with their external demands of society and the company's internal drive for the company to be more concerned about the environment, then the philanthropy activities begin to develop and lead to the company's concern towards the environment. ${ }^{13}$

At first the business world considers that the company only faces responsibility that rests on a single bottom line, the sole value of the comoany that is reflected in the financial condition of the company, but in its development company must also consider the social and environmental aspects (triple bottom line). Companies no longer just operate economic activities to create profit in maintaining the survival of their business, but also has a responsibility towards society (social) and the environment. $^{14}$

Since the House of the Representatives included the concept of CSR in the discussion of the Draft Law on Limited Liability Companies, ${ }^{15}$ pro and cons emerged from society, particularly from business venture. Those opposing the inclusion argue that CSR should voluntary. Those who implement CSR in the management of the company will experience firsthand the benefits of social responsibility accomplishments, therefore mandatory implementation is not necessary. Mandatory corporate social responsibility and the environment in the Law on Limited Liability Companies are considered to be burdensome, because it can increase the burden of operational costs. ${ }^{16}$

Conversely, supporters argue that if CSR is not regulated by the law the companies tend to ignore their social responsibility. Parties that support the inclusion of social responsibility in legislation hope that companies are able to participate in the process of sustainable development. A company is not a separate entity from the society and the environment in which it (the company) is located; a company is an integral part that only exists if it has a strong social legitimacy. To have strong legitimacy, a company must have a lot of benefits and concern for the social environment. ${ }^{17}$

The background of the inclusion of corporate social responsibility and the environment into a law described is by Akil Mochtar, Chairman of the Special Committee on the Law on Limited Liability Company in 2007. The obligations on social responsibility had to be done because many multinational companies operating in Indonesia abdicated from their responsibilities in managing the environment. Other drafter of the Law on Limited Liability Company, namely A. Partomuan Pohan stated that the inclusion of social and environmental responsibility into more appropriate legislation that is social and environmental responsibility should be interpreted as an instrument to reduce unethical business practices. Social and environmental responsibility is a mean to minimize the negative impacts of the production process of business to the public. $^{18}$

The enactment of Law No. 40 of 2007 on Limited Liability Companies, Corporate Social Responsibility, which was originally only a moral obligation and voluntary, turned into a legal obligation which must be carried out by a company in or related to the management of natural resources.

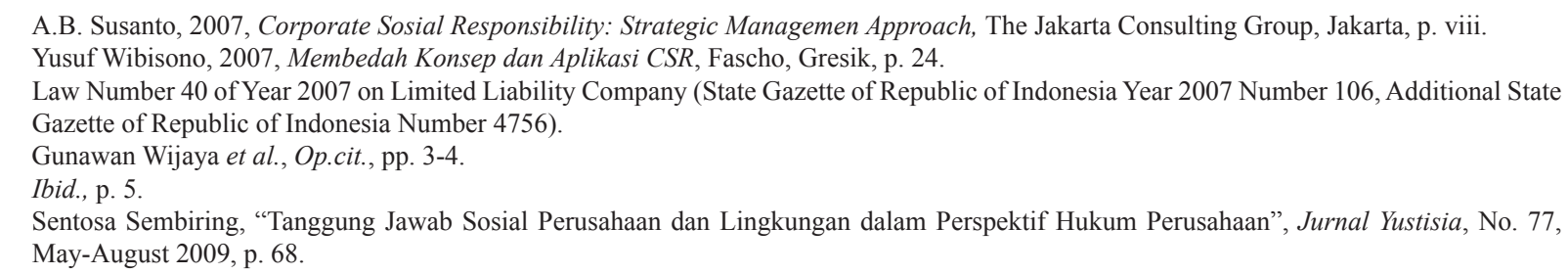


The regulation of corporate social responsibility (CSR) and the environment in Indonesia is listed in some legislations. Article 1 (3) of Law Number 40 of 2007 on Limited Liability Company (PT) states that:

Social and Environmental Responsibility is the commitment of the Company to participate in sustainable economic development to improve the quality of life and environment that benefits the Company itself, the local community and society in general.

Furthermore, in Article 74 paragraph (1) of Law Number 40 of 2007 on PerseroanTerbatas states that:

A Company that conducts its business activities in mining and/or related to the natural resources is required to implement corporate responsibility to the society and the environment.

If the company which business activities are related to natural resources does not fulfill its responsibility to the society and the environment, it will be penalized in accordance with the provisions of the legislation. ${ }^{19}$ The aforementioned sanction refers to any form of sanction governed by the related legislation. Thus, an agreement on corporate responsibility to the society and environment is not confined in one regulation, but spread over several laws depending on the form of the company and the company's activities. ${ }^{20}$

As stated in Article 1 (3) of Law Number 40 of 2007 on Limited Liability Company in which corporate responsibility on the society and environment is the company's commitment to improve the quality of the environment and people's lives, the company itself and local communities. This means that the presence of the company must be committed to empowering communities and managing the environment efficiently and providing benefits to the community. Act No. 4 of 2009 on Mineral and Coal Mining states that the mineral and coal mining are managed by expediency, justice, equity, sustainable and environmental friendliness. The purpose of mining is to increase the income of local people, regional society, the state, and create employment for the greater prosperity of the people. ${ }^{21}$

In realizing the purpose of mining, Act No. 4 of 2009 on Mineral and Coal includes regulation that substantially requires the formation and implementation of communal empowerment and development. Development and empowerment are a part of the implementation of corporate social responsibility which has been normalized into legislation. The problems that arises is that the normalization of corporate social responsibility as corporate responsibility has legal consequences for the company. Therefore as it has become the norm of law, then it becomes a necessity for companies to implement corporate responsibility to society and environment. If the company does not make a plan and/or implement programs or activities of community development and empowerment, the company will be given administrative sanctions. ${ }^{22}$

To protect the environment the government has issued Law No. 32 of 2009 on the Protection and Management of the Environment. In Law No. 32 of 2009 on the Protection and Management of the Environment, there are several instruments to protect the environment such as: Strategic Environmental Assessment, Environmental Impact Assessment, Environmental Permit, and others.

To support the aforementioned instruments, Law No. 4 of 2009 on Mineral and Coal Mining states that mining operation is carried out in the

19 Law Number 40 of 2007 on Limited Liability Company (State Gazette of Republic of Indonesia Year 2007 Number 106, Supplement to State Gazette of Republic of Indonesia Number 4756).

20 Law Number 4 of 2009 on the Mining of Mineral and Coal (State Gazette of Republic of Indonesia Year 2009 Number 4, Additional State Gazette of Republic of Indonesia Number 4959).

21 Law Number 4 of 2009 on the Mining of Mineral and Coal (State Gazette of Republic of Indonesia Year 2009 Number 4, Additional State Gazette of Republic of Indonesia Number 4959).

22 Law Number 4 of 2009 on the Mining of Mineral and Coal (State Gazette of Republic of Indonesia Year 2009 Number 4, Additional State Gazette of Republic of Indonesia Number 4959). 
form of mining licenses. Holders of Mining Permit (IUP) must submit a plan and the guarantee funds for reclamation and post-mining recovery. Guarantee funds for reclamation and post-mining recovery is applied to them if the permit holder does not carry out mining reclamation and post-mining recovery.

Incomprehensive normalization of corporate responsibility on society and environment will obviously lead to implementation that barely passes the minimum requirements as provided by the law. Companies that hold charitable activities or relating to the public (stakeholders) may be said to have implemented corporate responsibility on society and the environment.

According to Koswara Mission, ${ }^{23}$ companies implement social responsibility and the environment by creating programs on the empowerment of communities, where, according to Law No. 4 of 2009 on Mineral and Coal Mining, companies that hold the Mining Permit and Special Mining Permit are required to formulate development and empowerment of local communities. There are several problems associated with the regulation, among others, companies only empower communities adjacent to the company, therefore only a few people who will benefit from the existence of the company. Inequality in empowering the community raises increasingly visible gap between the poor and the rich.

Additionally, the costs incurred in the implementation of community development and empowerment program turned out to be done jointly by several companies, therefore rendering empowerment and community development ineffective. Joint cooperation of several companies in development and empowerment of the community saves the companies, therefore by the existence of the regulation the company does not take advantage by proportionality, and instead the company simply allocates these costs to a minimum.
The welfare of society are uneven, causing injustice to people who are not benefiting from the presence of the mining company. Yet according to the Constitution, welfare is intended for all Indonesian people, not just to some select few. In line with the Constitution, Jeremy Betham mentioned that the interest of the legislation is to produce happiness for the majority of the people. Other than that, the purpose of the law according to Bentham is to achieve the greatest happiness for the majority of the people. ${ }^{24}$ The current trend of management of natural resources only favors the few. The management of natural resources is supposed to bring benefits to the whole community, the company, and the environment, so that the greatest benefits will be achieved and justice will be felt by the entire community.

Another problem arising from the management of resources by companies, companies sometimes do not perform the obligation for reclamation and mine closure, resulting in damaged environment. The environmental destruction shows that the interest of the environment is disturbed; if the environment is damaged then the life of the whole ecosystem may also be disrupted. Such a situation would be disastrous for the community, as well as the reflection of the reputation of the company which prioritizes economic benefit regardless the community and the environment.

The negative impact of the company's presence in society is the emergence of various kinds of cases affecting the declining capacity of the environment and the social jealousy of the people in close proximity of the company because they do not receive welfare and benefit from the company's presence. Several cases have emerged in Indonesia, such as the case of Freeport Indonesia. Freeport opened mining operation on areas considered sacred by the surrounding communities, therefore the people feel that their freedom has

Interview with the Head of CSR Division PT Kalimantan Prima Persada on 15 June 2011.

Ahmad Ali, 2009, Menguak Teori Hukum (Legal Theory) \& Teori Keadilan (Judicialprudence): Termasuk Interpretasi Undang-Undang (Legisprudence), Prenada Media Group, Jakarta, p. 273. 
become limited because their land has become grounds for exploitation. In addition, PT Freeport also disposes mining waste into streams that exist around the mountains that pollute the surrounding environment. ${ }^{25}$ Therefore, the matters that have become principal problems in this article is about an alternative corporate social and environmental responsibility model that is active, participative and just?

\section{B. Research Methodology}

The article utilized research methodology that is juridical-normative which is legal research by utilizing secondary data sources, ${ }^{26}$ by compiling a conceptual framework, through the formulation of the provisions contained in the legislation that became the basis of research. ${ }^{27}$ Normative research on the principles of the law depart from premises that form the positive norms, namely Law No. 40 of of 2007 on Limited Liability Company, Law No. 4 of Year 2009 on Mineral and Coal Mining and Law No. 32 of 2009 on the Protection and Management of the Environment.

The writing of the research was conducted by using the approach of law (statutory approach) and conceptual approaches. Normative research can not escape legislative approach because the object of study revolves around various laws that are the focus and at the same time the central theme of a study, hence a normative research will definitely use legal approach although the study itself leads to the vacuum of law. ${ }^{28}$ Legislative approach is used in connection to legal regulations governing Limited Liability Companies (Act No. 40 of Year 2007), Mineral and Coal Mining (Act No. 4 of Year 2009), Protection and Management of the Environment (Law No. 32 of Year 2009). A conceptual approach, if one is to examine from the meaning of "conceptual", is derived from the the word which refers to abstract elements that represent classes of phenomena in a field of study that sometimes refers to the particular matters. One function of concept is emergence, objects that attract one's attention from a practical viewpoint and angle of the knowledge in mind and certain attributes. Then conceptual approach is used in connection with the concepts of corporate social responsibility, protection and management (including conservation) of the environment that must be considered by a coal mining company, so that welfare and social justice for the people is achieved.

Data sources from this study were obtained or collected by means of literature study to obtain secondary data, i.e data collected from a second hand or from other sources which had been available before the study was done. Secondary sources include comments, interpretation, or the discussion of the original material.

\section{Result of Research and Analysis \\ 1. Alternative Model for Corporate Social and Environmental Responsibility: Active, Participative, and Just}

The model of corporate responsibility to society and environment fundamentally serve as a method to shape a more effective program of social and environmental responsibility. In the literature, there is no model of corporate social responsibility that is discussed comprehensively on the implementation, but instead it discusses ideas that became the basis of the model on corporate responsibility to society and the environment. The much discussed basic idea is the existence of models on programs of corporate responsibility to society and the environment. One of such is programs of corporate social responsibility which focuses to the development and empowerment.

Empowerment is a process and a goal. As a process, empowerment is a series of activities that strengthens the capabilities or the empowerment of

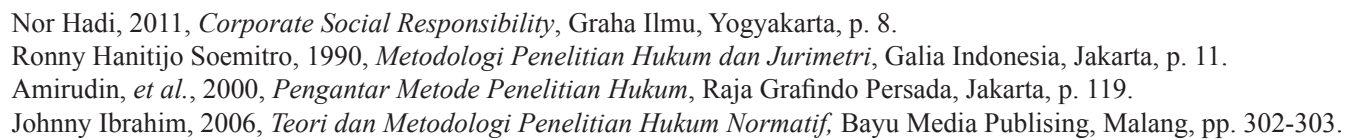


vulnerable groups in society, including individuals who experience poverty. As a goal, empowerment aims to reach a circumstance or the results to be achieved by a social change; in which empowered community has the power or knowledge in meeting their needs whether physical, economic, social and such as having confidence, able to convey their aspirations, having livelihoods, participate in social activities, and independent in carrying out the tasks of life. ${ }^{29}$

Empowerment of community is more than just strengthening the local economy. It includes increased participation of citizens in the political sphere and strengthening the capacity of the community to achieve their goals in accordance with their aspirations, and capacity of their available resources. To be able to empower the community, it is necessary to plan or scheme an indicator of empowerment, as well as to design appropriate strategies to make development programs and community empowerment. In practice, the implementation of development and empowerment programs by companies is applied superficially without good planning or a research on the needs of the surrounding communities. Although there are some companies that have a policy of corporate social responsibility, the policy usually is only adopted from the parent company resulting in programs that are not in accordance with what is required by the community.

In an effort to devise appropriate strategies to make development programs and community empowerment, so as to improve the quality of life and the environment, the authors attempted to formulate an alternative model of corporate social and environmental responsibility that is active, participative, and just. The model puts more emphasis on forms of community involvement to participate in the formulation of development programs and community empowerment. The active participation module is intended to allow communities to have a balanced force in the fight for their aspirations by means of lawsuits to fight for their rights. The concept of justice is included into this model because the center of welfare os the presence of justice (every person is given the same rights) in the struggle for their rights as citizens.

The model of corporate social and environmental responsibility that is active, participative and just focuses on the active participation of the community to plan and implement corporate social responsibility programs. In the model of corporate social responsibility that is active, participative, and just, the most important is the active role of the company to form a community organization as a forum for communication between the company and the community as well as with the government. Implementing corporate social responsibility programs by the company will be easier with good communication between the company and the community as the company becomes aware of the needs of the community, thus allowing people to follow the program and the quality of life and well-being of society will increase.

The model of corporate social responsibility that is active, participative and just begins by the formulation of the vision and mission by mining companies. Vision is a picture of the future, realistic and embodied within a certain time. Hax and Majluf mentioned that vision is a statement that is a method to communicate the reason for the founding of the organization in terms of interest and focus to the framework and the relationship between the organization and stakeholders (human resources, community, other relevant parties), as well as stating the main target of the organization's performance in terms of growth and development. ${ }^{30}$ Following the conception of vision, vision is then elaborated in operatonal manner by what is known as mision. Mission is a statement about the matters that must be achieved for the organization to the 
interested parties. The statement of mission must clearly display the goals of the organization and the key activities of the aforementioned organization. Explicitly mission contains what must be done to achieve the goals, and invites the public to the main areas of development that are involved. The purpose is the description of the mission which is a goal to be achieved or generated within a predetermined time. In strategic planning, formulation of objectives will direct the formulation of objectives, strategies, programs, and activities in the mission. ${ }^{31}$

The model begins by forming the foundation of policies in the company in which the company applies vision and mission, goals, targets, policies and strategies to be later mapped in field by creating a medium or organization as a method of communication and participation by the people. The organization is useful to map the potential and deficiencies of the community. When the potential and deficiencies are known, company may create programs that refers to development on social, economy, environment, politic, personal and spiritual aspects with the goal of improving the quality of environment, life of the people and the company itself.

There are three important reasons why companies undertake community development activities: $^{32}$

1. Local Permit

In general, a company obtains operational permita formal institution, in this case as the embodiment of the culture department of the national and local governments with reference to regional autonomy, but itnever asked for permission from the local community as the owners of communal areas where the company intends to operate.
Local permit refers to the inclusion of the local community ${ }^{33}$ within the scope of the company's business, and the company as newcomers and the local community to acquire mutual benefit. Permit is an absolute necessity to the company in order to perpetuate its activities in the customary rights of the local community as part of society. (See informative chart on the impact of mining activities)

2. Organize and create future strategies, by adapting his company to the social and cultural life of local community, the company can acquire and create business strategies through active cooperation with the community through programs of community development. Reputation of good relations between the company and the local community in the development of community aids in the creation of condition that is conducive to all mining activities.

3. As a Mean to Aid the Fulfillment of the Business Operation

Community development programs have the potential to increase business value to the company. The value can only be maximized when the company planned development program strategy through:

a. Defining objectives, the company should be able to identify the advantage in implementing community development. This can help to form the basis for planning purposes and objectives of the company.

Budimanta Arif, et al., 2003, Metode dan Teknik Pengelolaan Community Development, ICSD (Indonesia Center For Suistainable Development), Jakarta, pp. 30-31.

33 Community is a group of people who inhabit a certain area in which all of its members interact with each other, owning a clear division of roles and status, having the ability to enforce order to its members. In comparison to a community of peoples in ceremonial situation by nonutilization of status that applies in society, the fundamental relationship lies in personal relationship and not on the roles that have been set by social order and sacred in character. Ibid., p. 28. 
b. Understanding the expectations of the community and stakeholders, possessing the understanding that communities have different expectations from stakeholders, and this may help to predict and analyze potential conflicts and expectations in general. Creating a program of general purpose community so that it can help companies and communities to build confidence, improve transparency and define the goals and objectives together.

The three methods may be implemented well if the company establishes good communication with the community. The company communicates with the public by establishing an organizational structure in the community. Structure of the organization is created by forming organizational design. Organizational design itself is a form of rules, processing activities, and formal relationship within an organization. Inside, there is the development of the overall structure of the organization both units and sub-units, as well as definition of the roles and processes in more detail in unit or sub unit. ${ }^{34}$

The formation process of formal relations undertaken by the company and the community is done with the participatory method. Participatory method views the community not only as an object but also the subject of development that is able to set goals, control resources and direct the development process to improve their living standards. ${ }^{35}$ According to participatory method it is the community itself who should be able to formulate suitable development activities in the region. In this case, the success of development is highly dependent on community empowerment and public participation in determining the appropriate level of priority development program depending on the needs of society and the strengthening of local institutions. ${ }^{36}$

Relating to theimplementation of participatory method, there are several forms of participation by the people which display the highest and lowest forms of participation. By participating, companies and the public can directly conjure programs to empower the community by looking at existing resources and by establishing or mapping the areas that will be developed and empowered. In the participation of an ogrnanization, there needs to be awareness on the position of the people in the communal stucture who are able to directly participate and those who are incapable of participation. Kweit noted that in general, people with higher socioeconomic status are likely to participate more. Another matter that must be considered in the formation of community organizations is the mindset of the society. ${ }^{37}$ The mindset of the community could be an obstacle in the implementation of participation, because of differences in the mindset of the company and the community must be united through a social approaches. Differences in the mindset that if not managed properly will cause conflicts and rejection of the company's activities. Differing mindset is caused by difference in the background.

If studied further, the role of the active participation of the community can improve the power and strengthen the bargaining position of the community with the company. Strengthening the bargaining position is convenient in the struggle for their rights. In the struggle for their rights, the public can file a class action lawsuit. With the establishment of the organization as a forum for public communication to convey their aspirations as well as supervision of the companies in carrying out the activities, therefore all forms of sanctions imposed by the legislation can be enforced effectively.

\footnotetext{
Andi Utama, "Mendesain Struktur Organisasi”, http//www.ilmusdm.wordpress.com, accessed 1 October 2015.

Mella Ismelina F.R., Pemberdayaan Sebagai Upaya Peningkatan Kesadaran dan Partisipasi Masyarakat dalam Pelestarian Fungsi Lingkungan Pesisir, Disertasi, Univeritas Diponegoro, Semarang, p. 34. 
Participation of the people in the making of community development and community empowerment allows the public to direct the dimensions of development and community empowerment. The dimensions of development and empowerment aim to create an increased quality of the environment and increasing the quality of society and the growth of the company. Furthermore, development programs and community empowerment created by the participation of the community could be instrumental in protecting and managing the natural resources available. In that case, the protection of the environment may act to safeguard the environment from the actions of companies that do not conform to the conservation and sustainability of the environment. With regards to natural resource management, the public may be involved in the management of the environment in which mining activities have or are currently taking place. Companies and communities may work together to overcome environmental challenges by carrying out environmental development program.

Regarding implementation of community development and empowerment programs, there are four models that may be utilized. First, the direct model. The direct model is implemented by allocation of budget by the company, i.e. $2.5 \%$ of the profits to implement the programs. Second, the foundation model. The model is applied through the company's charitable foundation. However, its activities must be in accordance with what has been designed by the company and the community. While the foundation may be administratively separate from the company, the foundation is the representative of the company, therefore it must synergize with the company to establish and implement development programs and community empowerment by active participation from the people in the formation and implementation stages. ${ }^{38}$

Third, partnership with NGOs or third parties. For example, with universities, or other companies which are associated with community development projects. In the third model, the company simply allocates budget and not obliged to do assessment, monitoring, evaluation, conception of programs, etc. Fourth, the consortium model, several companies are joined as consortium and the consortium implements and plan programs on development and empowerment of the community. ${ }^{39}$ From the four models, the implementation must be adjusted to the situation in the field and the needs of the community.

The next stage is evaluation and monitoring. The success or failure of the implemented programs to the community may be seen from the results of the monitoring and evaluation of the programs. Therefore that monitoring and evaluation is a matter of great importance which is related to the planning of future programs. Implementation of monitoring is conducted on the phases of underway mining activities, therefore the advantages and disadvantages of the program are known. ${ }^{40}$ Evaluation is an assessment process. In the effort to evaluate a program, one must first plan and organize the human resources. Evaluation aids associated individuals in various development programs to evaluate the realities of what has been achieved. Model for corporate social and environmental responsibility that is active, participative and just is illustrated as below:

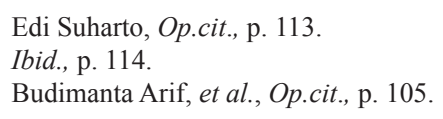




\section{Illustration 1.}

\section{Alternative Model for Corporate Social and Environmental Responsibility that is Active, Participative and Just}

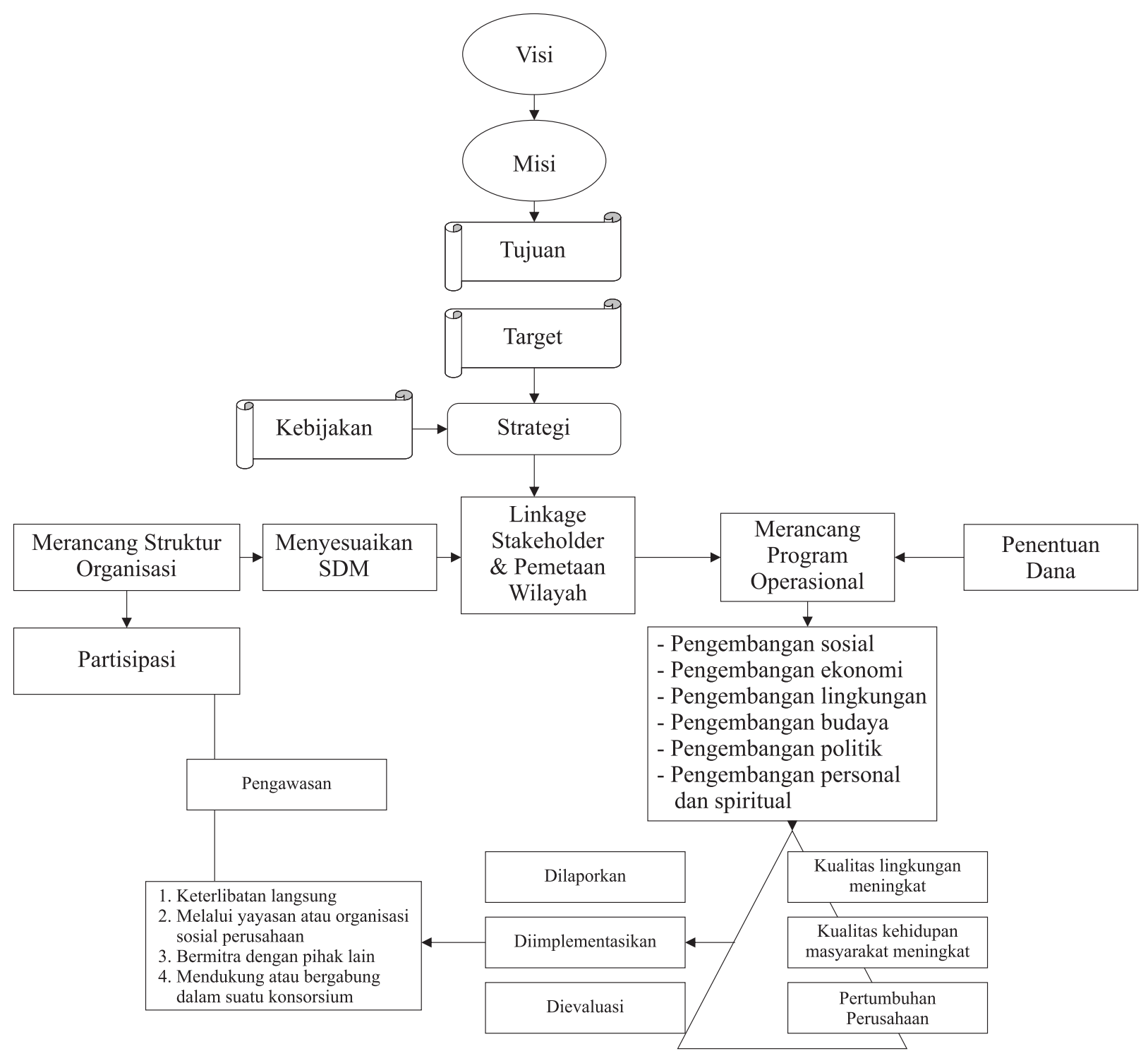

Source: Arif Firmansyah et al., LPPM Universitas Islam Bandung, 2015-2016.

\section{Conclusion}

The alternative model of corporate social and environmental responsibility for mining companies operates by establishing plans ranging from vision, mission, goals, strategies and policies to give freedom to participate in the formulation and overseeing the implementation of the programs of corporate social responsibility by mining companies, and then the implementation of the corporate social and environmental responsibility is reported and evaluated. Thus, people who are involved in the program experience improvement to their quality of life.

In issuing the mining permit, the government should consider the aspirations and participation of the community for community development and empowerment program as a condition for the issuance of mining permit, hence when the mining companies operate are no conflicts between companies and communities. 


\section{BIBLIOGRAPHY}

\section{A. Book}

Akdon, 2006, Strategic Managemen for Educational Management, Alfabeta, Bandung.

Ali, Ahmad, 2009, Menguak Teori Hukum (Legal Theory) \& Teori Keadilan (Judicialprudence): Termasuk Interpretasi Undang-Undang (Legisprudence), Prenada Media Group, Jakarta.

Amirudin, et al., 2000, Pengantar Metode Penelitian Hukum, Raja Grafindo Persada, Jakarta.

Arif, Budimanta, et al., 2003, Metode dan Teknik Pengelolaan Community Development, ICSD (Indonesia Center for Suistainable Development), Jakarta.

Buku Panduan Rakor dan Pameran Program Tanggung Jawab Sosial (CSR/PKBL) Perusahaan sebagai Alternatif Pembiayaan Pembangunan di Jawa Timur.

Departemen Pendidikan dan Kebudayaan \& Balai Pustaka, 1995, Kamus Besar Bahasa Indonesia, Departemen Pendidikan dan Kebudayaan \& Balai Pustaka, Departemen Pendidikan dan Kebudayaan \& Balai Pustaka, Jakarta.

Hadi, Nor, 2011 Corporate Social Responsibility, Graha Ilmu, Yogyakarta.

Hatta, Mohammad, 1967, Ekonomi Terpimpin, Djambatan, Jakarta.

Ibrahim, Johnny, 2006, Teori dan Metodologi Penelitian Hukum Normatif, Bayu Media Publising, Malang.

Saleng, Abrar, 2004, Hukum Pertambangan, UII Press, Yogyakarta.

Soemitro, Ronny Hanitijo, 1990, Metodologi Penelitian Hukum dan Jurimetri, Galia Indonesia, Jakarta.

Susanto, A.B., 2007, Corporate Sosial Responsibility: Strategic Management Approach, The Jakarta Consulting Group, Jakarta.
Sutikno et al., 2006, Ekonomi Sumber Daya Alam, Badan Penerbit Fakultas Ekonomi Universitas Brawijaya, Malang.

Wibisono, Yusuf, 2007, Membedah Konsep dan Aplikasi CSR, Fascho, Gresik.

Widjaya, Gunawan, et al., 2009, Risiko Hukum \& Bisnis Perusahaan Tanpa CSR, Forum Sahabat, Jakarta.

\section{B. Research Result}

Kirana, Rosita Chandra, 2009, Studi Perbandingan Pengaturan tentang Corporate Sosial Responsibility di Beberapa Negara dalam Perwujudan Prinsip Good Corporate Governance, Thesis, Master Program Universitas Sebelas Maret, Surakarta.

F.R., Mella Ismelina, Pemberdayaan Sebagai Upaya Peningkatan Kesadaran dan Partisipasi Masyarakat dalam Pelestarian Fungsi Lingkungan Pesisir, Dissertation, Univeritas Diponegoro, Semarang.

\section{Journal Article}

Sembiring, Sentosa, "Tanggung Jawab Sosial Perusahaan dan Lingkungan dalam Perspektif Hukum Perusahaan”, Jurnal Yustisia, No. 77, May-August 2009.

\section{Internet Articles}

MohamadFaiz, Pan, "PenafsiranKonsep Penguasaan Negara Berdasarkan Pasal 33 UUD 1945 dan Putusan Mahkamah Konstitusi", http://www. jurnalhukum.blogspot.com, accessed on 1 October 2015.

Utama, Andi, "Mendesain Struktur Organisasi", http//www.ilmusdm.wordpress.com, accessed on 1 October 2015.

Sudarmanto, R. Gunawan, "Konsep Dasar Ekonomi Pancasila", http://blog.unila. ac.id/radengunawans/files/2010/Makalah..., accessed on 1 October 2015. 


\section{E. Government Regulation}

Law Number 40 of 2007 on Limited Liability Companies (State Gazette of the Republic of Indonesia Year 2007 Number 106, Supplemenet to State Gazette of the Republic of Indonesia Number 4756).

Law Number 4 of 2009 on Mineral and Coal Mining (State Gazette of the Republic of Indonesia
Year 2009 Number 4, Supplement to State Gazette of the Republic of Indonesia Number 4959).

Number 32 of 2009 on Environmental Protection and Management (State Gazette of the Republic of Indonesia Year 2009 Number 140, Supplement to State Gazette of the Republic of Indonesia Number 5059). 